\title{
ETHEPHON SPRAYS AS A DEFOLIANT IN 'NIAGARA ROSADA' VINE SUBJECTED TO TWO CROP PRODUCTION PER YEAR ${ }^{1}$
}

\author{
THIAGO VIEIRA DA COSTA², RAFAELA VIEIRA FAÇANHA ${ }^{3}$,OÃO ALEXIO SCARPARE FILHO ${ }^{4}$
}

ABSTRACT - In climate region Cwa of the State of São Paulo the technique of double cropping the grapevine is possible, however, when it is time for the second pruning of the crop, most of the vine's leaves are still in the plant, posing the problem that the use of ethephon as a defoliant could increase leaf senescence and improve the vine management. The objective of this study was to evaluate the effects of ethephon spray as a defoliant in the development and production of the 'Niagara Rosada' vine when subjected to double cropping, and the influence this bioactivator may have on carbohydrate reserves in the branch. The experiments were conducted in a commercial, non-irrigated area in agricultural years of 2011/2012 and 2012/2013. The length, diameter and total carbohydrate reserves of the branches, as well as bud break, number of clusters, crop production, length, width and mass of cluster, berry diameter, soluble solids and titratable acidity were evaluated. Ethephon treatments were applied at a concentration of 1,440 $\mathrm{mg} \mathrm{L}^{-1}$ and 2,160 mg L-1 at 20 and 15 days before pruning. As a control, the vines were defoliated by hand at the time of pruning. A randomized block experimental design was used. Data was subjected to analysis of variance and means were compared by the Tukey test at 5\% significance level. In conclusion, we propose that ethephon sprays promoted vine defoliation and improved the bud break, altered plant development and crop production. This was not due to increases in concentration of carbohydrate reserves in the branches, but due to a higher induction stimulus of bud break, which allowed the vines to express their higher yield capacity.

Index terms: Vitis labrusca L., pruning, defoliation, carbohydrate reserves.

\section{AVALIAÇÃO DO USO DO ETEFOM COMO DESFOLHANTE NA VIDEIRA 'NIAGARA ROSADA' SUBMETIDA À PRODUÇÃO DE DUAS SAFRAS ANUAIS}

RESUMO- Em região de clima Cwa do Estado de São Paulo a técnica de colheita de duas safras de uva por ano é possível, no entanto, no momento da realização da segunda poda de produção as plantas encontram-se enfolhadas, levantando a questão de que uso do etefom como desfolhante poderia aumentar a senescência e melhorar o manejo da cultura. O objetivo do trabalho foi avaliar o efeito do etefom como desfolhante no desenvolvimento e produção da videira 'Niagara Rosada' quando submetida a duas safras, e a influência que esse bioativador pode ter no teor de carboidratos presentes nos ramos. O experimento foi conduzido em área comercial em videiras não irrigadas nos anos agrícolas de 2011/2012 e 2012/2013. O comprimento, diâmetro e teor de reservas de carboidratos totais dos ramos, brotação, número de cachos, produção, comprimento, largura e massa dos cachos, diâmetro de bagas, teor de sólidos solúveis e acidez titulável. Os tratamentos de etefom foram aplicados nas concentrações de $1.440 \mathrm{mg} \mathrm{L}^{-1}$ e $2.160 \mathrm{mg} \mathrm{L}^{-1}, 20$ e 15 dias antes da poda de produção e, como tratamento testemunha foi realizada a desfolha manual no momento da poda. $\mathrm{O}$ delineamento estatístico foi em blocos casualizados, os dados foram submetidos a análise de variância e as médias comparadas pelo Teste de Tukey ao nível de 5\% de significância. Como conclusão, nós propomos que a aplicação de etefom em folhas adultas de videiras, antes da poda de produção de verão, estimula a queda de folhas, induz a brotação, altera o desenvolvimento da planta e sua produção. Isto não foi devido ao aumento na concentração das reservas de carboidratos nos ramos e sim ao maior estímulo à brotação. $\mathrm{O}$ maior estímulo à brotação fez com que as plantas expressem sua maior capacidade de produção.

Termos para indexação: Vitis labrusca L., poda de produção, desfolha, reservas de carboidratos.

${ }^{1}$ (Trabalho 023-15). Recebido em: 09-01-2015. Aceito para publicação em: 30-11-2015.

${ }^{2}$ Agricultural Engineer MSc., Doctoral student in Phytotechny, ESALQ/USP - Piracicaba-SP - E-mail: costavieirat@gmail.com

${ }^{3}$ Biologist MSc., Doctoral student in Plant Physiology, ESALQ/USP - Piracicaba-SP - E-mail: rafaelavieiraf@gmail.com

${ }^{4}$ Agricultural Engineer, Associate Doctor Professor - Department of Plant Production of ESALQ/USP, CNPq Scholarship, level 1.

Piracicaba-SP - E-mail: jascarpa@usp.br 


\section{INTRODUCTION}

The State of São Paulo produces about 147,000 tons of grapes, standing out as one of the largest table grape growers of Brazil. In this context, the 'Niagara Rosada' vines correspond to $51 \%$ of total State production (IEA, 2014), and is mainly grown in Aw climates (Jales region) and Cwa (Jundiaí).

In Cwa climate conditions, production pruning of 'Niagara Rosada' grape is traditionally held in the winter and the harvest occurs between the months of December and January. Winter pruning is also known as dry pruning as plants are defoliated and the pruning is performed in the phase of reserve mobilization with a short pruning (with one or two buds) (SCARPARE et al., 2011).

The producers from this region adopted the summer production pruning, also known as green pruning because the plants are leafy. This pruning is carried out in the summer, during the phase of reserve accumulation and is considered long, because the branches are pruned in the fourth or fifth bud (SCARPARE et al., 2011).

With the adoption of this pruning, a new production cycle starts and the harvest takes place between the months of June and July. That is how the production of two harvests per crop year happens.

As in the summer production pruning plants are fully leafy, one of the techniques used for defoliation of the vine is spraying the adult leaves with etefom product. This technique is used in the climate of the Aw region of the State of São Paulo since 2004 (FRACARO et al., 2004). The use of etefom as a defoliant has also been studied in cultures as the atemoya plants (HAWERROTH, et al., 2014).

It was observed that plants treated with ethephon exhibit more uniform and vigorous sprouting, and some studies also indicate relationship between the content of carbohydrates in plants and fertility of the buds, (CANDOLFI-VASCONCELOS and KOBLET, 1990; BENNETT et al., 2005; SMITH and HOLZAPFEL, 2009; SABBATINI and HOWELL, 2010; PELEGRINO et al., 2014; ROSA et al., 2014) which has led some researchers to conclude that this product induces plants to accumulate higher amounts of reserves in the branches, responsible for a greater number of shoots.

In this regard, the objective of this study was to verify the effect of the application of etefom before the summer production pruning, on the accumulation of soluble carbohydrate reserves in the branches of 'Niagara Rosada' vine and the influence of this bioactivator in the development and production of this vine, grown under Cwa climate conditions.

\section{MATERIAL AND METHODS}

The study was conducted in a commercial vineyard of a traditional producer, located in the county of Atibaia, west region of the State of São Paulo, located at latitude $23^{\circ} 07^{\prime} 01^{\text {' }}$ South, longitude $46^{\circ} 33^{\prime} 01^{\prime \prime}$ West and altitude of $803 \mathrm{~m}$. According to the Köppen and Geiger classification (1936), the regional climate is Cwa (tropical of altitude, with summer rains and dry winters, with average temperatures higher than $22^{\circ} \mathrm{C}$ in the hottest month, and less than $18^{\circ} \mathrm{C}$ in the coldest month).

The average annual temperature in the county is $20.0^{\circ} \mathrm{C}$, with a minimum average of $13.8^{\circ} \mathrm{C}$ and the maximum average of $26.1^{\circ} \mathrm{C}$. The average rainfall is $1,510 \mathrm{~mm} \mathrm{yr}^{-1}$ (CEPAGRI, 2014).

It was used the Niagara Rosada variety grafted on rootstock IAC 766, planted in espalier. The rootstocks were planted in June 2005, in spacing of one meter between plants and two meters between rows and grafted in July 2006.

The selected plants were fully leafy and had uniform size and vigor. After the selection, the vines were identified with polyethylene plates and ribbon of coloring non-woven fabric (TNT). All plants have been pruned in the fifth bud and then received application of hydrogenated cyanamide at $5 \%$ in the last two buds.

Two summers production pruning were evaluated. In the agricultural year 2011/2012 the summer production pruning was held on February $7^{\text {th }}$, 2012 and the harvest on June $27^{\text {th }}$. In the agricultural year 2012/2013 pruning was held on February $11^{\text {th }}, 2012$ and the harvest on June $29^{\text {th }}$. Due to the management used by the producer, in the second experiment were used plants from the neighboring plot, which were under the same support system, age, spacing and rootstock.

The experiment consisted of the following treatments: T1- control (manual defoliation at the time of pruning); T2 - ethephon application in the concentration of $2,160 \mathrm{mg} \mathrm{L}^{-1} 20$ days before production pruning; T3 - ethephon application in the concentration of $1,440 \mathrm{mg} \mathrm{L}^{-1} 20$ days before production pruning; $\mathrm{T} 4$ - ethephon application at a concentration of $2,160 \mathrm{mg} \mathrm{L}^{-1} 15$ days before production pruning; T5 - ethephon application in the concentration of $1,440 \mathrm{mg} \mathrm{L}^{-1} 15$ days before production pruning. In the preparation of the solution was used pure water without salinity and obtained at the end a solution with $\mathrm{pH} 5$.

To obtain the solutions at concentrations 
of $1,440 \mathrm{mg} \mathrm{L}^{-1}$ and $2,160 \mathrm{mg} \mathrm{L}^{-1}$ we used the commercial product $\left(\right.$ Ethrel $\left.^{\circledR}{ }^{\circledR} 720\right)$ containing 720 $\mathrm{g}$ of ethephon $\mathrm{L}^{-1}$ at doses of $200 \mathrm{ml}$ and $300 \mathrm{ml}$ for 100 liters of water, respectively. The application was made with an electric backpack sprayer of 18 L, Superherb ${ }^{\circledR}$ model.

Cultural practices used were adopted conventionally for the crop in the region.

The following variables were evaluated:

Date of sprouting: it is considered as the date of sprouting when more than $50 \%$ of the sprouts were in stage 5 (green tip) according to Eichhorn and Lorenz classification (1984). Length of branches: the length of the branches was measured at the insertion point of the spur to the apex, at the time of lopping (flowering). For this evaluation, we used a graduated tape $(\mathrm{cm})$ and two branches were sampled per plant, totaling twenty branches per treatment. Content of total carbohydrate reserves in the branches: it was collected five samples of each treatment 20 days before pruning installation, in which was removed pieces of branches from the $6^{\text {th }}$ to the $8^{\text {th }}$ bud and on the day of the production pruning. The samples were dried at $65^{\circ} \mathrm{C}$, crushed and sent to the Postharvest and Vegetables Laboratory (ESALQUSP) for quantification of total soluble carbohydrates (TSC), according to the method proposed by Dubois et al. (1956). Number of clusters: by counting the number of clusters per shoot and per plant in the fruiting stage. Production: the crop was harvested when the fruits reached a pinkish and uniform color characteristic of the variety. The grapes were harvested in the morning and transported to the packing house. The fruits were weighed, with the aid of a scale (brand Bel ${ }^{\circledR}$ model Mark L) and the results expressed in $\mathrm{kg}$ plant $^{-1}$. Physico-chemical characterization of fruits: from each plant were collected six clusters for measuring length, diameter and mass, totaling 60 clusters per treatment and four clusters for soluble solids evaluation, titratable acidity, size and mass of the berries. For the soluble solids analysis were sampled ten berries per cluster, being collected 3 berries in each cluster located in the upper portion, 3 berries in the lower portion and 4 berries located in the middle portion of the cluster. After removing the peel with a spoon, the berries were crushed manually in a sieve and the grape must packed in a becker. A drop of the grape must was placed in a digital refractometer Atago brand, model Pallet 101, being performed two readings by repetition and the results expressed in ${ }^{\circ}$ Brix. For the evaluation of titratable acidity, $10 \mathrm{~g}$ of the grape must were homogenized in $100 \mathrm{~mL}$ of distilled water and the titrated solution with $\mathrm{NaOH} 0.1 \mathrm{~N}$ under stirring until reaching $\mathrm{pH} 8.10$ (turning point of the phenolphthalein) using a digital pHmeter (Tecnal, Tec 03 MP) calibrated with standards of 4.0 and 7.0 (CARVALHO et al., 1990). The results were expressed in percentage (\%) of tartaric acid. The length and width of the clusters were evaluated by digital caliper of $0.01 \mathrm{~mm}$ resolution. The number of berries per cluster was estimated by the ratio between the mass of ten berries and the mass of grapes without stalks.

The experimental design was randomized blocks with five repetitions, consisting of two plants per plot, totaling 50 plants. Data were subjected to analysis of variance and the means compared by Tukey test at 5\% significance level.

\section{RESULTS AND DISCUSSION}

The application of ethephon did not alter the concentration of TSC in the production branches (Table 1). In the agricultural year 2011/2012 the concentration of TSC ranged from 74.80 to 81.59 $\mathrm{g} \mathrm{kg}^{-1} \mathrm{DM}^{-1}$ and 89.02 to $97,10 \mathrm{~g} \mathrm{~kg}^{-1} \mathrm{DM}^{-1}$ in the agricultural year 2012/2013. The results of this study indicate that the application of ethephon did not affect the CST accumulation in production branches.

The accumulation of reserves occurs mainly between maturation and leaf fall, having as the main drains in this period, the fruit and root growth, followed by the accumulation in the branches and roots (HOLZAPFEL et al., 2006; ZUFFEREY et al., 2012; PELEGRINO et al., 2014). The application of ethephon caused senescence of the leaves, damaged the development of photoassimilates and made the plants instead of remaining at the stage of accumulation of reserves were encouraged to sprout and start new growth cycle.

The sprouting of plants sprayed with ethephon occurred between the fifteenth and the eighteenth day, and was on average 17 days after pruning. In the control treatment, the average was 22 days and ranged from the twentieth to the twentyfourth day after pruning. The application of ethephon promoted higher number of sprouting of the basal buds which in some cases can compromise the buds that will be used to produce the next harvest.

Regardless of the dose studied and date of application, the application of ethephon promoted the formation of branches with greater length in relation to the control treatment. The branches' growth in plants treated with ethephon was on average $26 \%$ higher than in the agricultural year 2011/2012, and $123 \%$ higher in the agricultural year 2012/2013. Over the same period the increase in the diameter of the 
branches was $33 \%$ and $69 \%$, respectively.

As the plants treated with ethephon sprouted before, it is justifiable that the branches of these plants presented greater growth in length and diameter; however this higher growth was due not only to an early sprouting, but the action of ethephon in stimulating sprouting. This was observed by Dokoozlian and Williams (1995), which found higher growth in vine branches submitted to application of hydrogen cyanamide in the concentration of 1.25 and $2.50 \%$ and particularly were exposed to a smaller time of cold.

The ethephon action form is not yet fully understood, and just as occurs with the hydrogen cyanamide, may be related to its effects on the cells respiratory system and interference in some enzymatic processes that control the plant rest. In nature, the process of bud dormancy breaking is triggered by low temperatures (NENDEL, 2010), which reduce the activity of catalase in the tissue of the plants (SHULMAN et al., 1986). It should be also consider that the dormancy of the deciduous fruit trees buds is regulated by a balance between promoters and growth inhibitors (WALKER, and SEELEY, 1973).

Ethephon influenced the plant production potential. The number of clusters and production per plant was higher in vines that received ethephon application, except for treatments in concentrations of 2.160 and $1.440 \mathrm{mg} \mathrm{L}^{-1}$ of this regulator twenty days prior to pruning in the agricultural year 2011/2012, which did not differ from the control treatment.

It is known that the production potential of a given year is established in the previous cycle (CANDOLFI-VASCONCELOS and KOBLET, 1990; PONI et al., 2006; CANDOLFI-VASCONCELOS et al., 2009). It is important to note that production depends not only on early flowers formed in the previous cycle, but the capacity of this plant to express this potential.

Factors such as unfavorable weather conditions, nutritional imbalance and low level of reserves in the plant can inhibit the development of the cluster. Any imbalance between the factors involved in the formation of inflorescence primordia can take the not compromised primordia to differentiate into tendril or vegetative sprouting (SHIKHAMANY, 1999). According to Srinivasan \& Mullins (1981), several factors influence the fertility buds on vines, such as the vigor of the branches, temperature, light intensity, mineral nutrition, phytohormones levels and plant growth regulators applications.

Studies show that the number of clusters can vary due to the use of plant growth regulators. In these studies it was found that there was an increase in the number of clusters and yield per plant in vines treated with hydrogen cyanamide (MIELE, 1991; PIRES et al., 1999; BOTELHO et al., 2002; WERLE et al., 2008).

Thus, ethephon did not influence the differentiation of buds, but encouraged the budding and allowed the vines subjected to the action of this bioactivator express a production potential closer to what might be understood as the maximum capacity of the plant production.

In the agricultural year 2011/2012, the average yield of the plants treated with ethephon was $3.25 \mathrm{~kg}$ plant $^{-1}$ and the control treatment was 1.57 $\mathrm{kg} \mathrm{plant}^{-1}$. During the growing season 2012/2013 plants under the application of ethephon produced on average $4.11 \mathrm{~kg} \mathrm{plant}^{-1}$ and those belonging to the control treatment $1.13 \mathrm{~kg} \mathrm{plant}^{-1}$, in both cases the largest production is due primarily to the greater number of clusters per plant.

It was observed higher cluster weight in plants that received the application of ethephon in the agricultural years 2011/2012 and 2012/2013 (Table 2 ). The greater cluster weight should be not to the size of berries, but to the greater number of those, which consequently reflects in a greater length, width and cluster weight. The evaluation of the number of berries was included in the 2012/2013 harvest and according to this evaluation, plants subjected to ethephon application produced clusters with an average of 55 berries and the control treatment produced clusters with about 40 berries. It is likely that the biggest stimulus to budding caused by application of ethephon, allowed plants to express larger berries fixation capacity per cluster.

The cluster weight of plants treated with ethephon was $42 \%$ and $46 \%$ higher than those of the control treatment in the first and second experiment, respectively. The soluble solids content in the agricultural year 2011/2012 only differed between plants witness $\left(11.90^{\circ} \mathrm{Brix}\right)$ and those belonging to the treatment $5\left(11.17^{\circ} \mathrm{Brix}\right)$ (ethephon application in the concentration of $1,440 \mathrm{mg} \mathrm{L}^{-1} 15$ days before pruning).

During the agricultural year 2012/2013, it was verified a smaller content of soluble solids in the clusters of plants treated with ethephon. The average content of plant clusters belonging to the control treatment was $12.21{ }^{\circ}$ Brix, in the plants treated with ethephon that content fell to $11.13^{\circ} \mathrm{Brix}$, there was no influence in relation to the dose and date of application.

The lowest soluble solids concentrations are 
due to the production of greater numbers of berries per clusters and consequent increased competition for photoassimilates in plants treated with ethephon. It is known that the soluble solids content of the berry is inversely proportional to the acidity value (PONI et.al., 2006; SABBATINI and HOWELL, 2010). However, the acidity values of the fruits treated with ethephon were lower and are due to the action of this product on the ripening process of fruits, a fact also confirmed by Leão et al. (2015).

TABLE 1- Content of total soluble carbohydrates (TSC), length and diameter of branches, number of clusters and yield per plant in Niagara Rosada vine depending on ethephon application before summer pruning in the county of Atibaia-SP.

\begin{tabular}{|c|c|c|c|c|c|}
\hline \multicolumn{6}{|c|}{ Agricultural year 2011/2012 } \\
\hline Treatment & $\begin{array}{c}\text { TSC } \\
\left(\mathrm{g} \mathrm{k}^{1} \mathrm{DM}\right)\end{array}$ & $\begin{array}{c}\text { Branches Length } \\
\text { (cm) }\end{array}$ & $\begin{array}{c}\text { Branches } \\
\text { diameter } \\
(\mathrm{mm})\end{array}$ & $\begin{array}{l}\text { Clusters } \\
\left(\mathrm{n}^{\mathbf{0}} \text { plant }^{-1}\right)\end{array}$ & $\begin{array}{c}\text { Yield } \\
\left(\text { kg plant }^{-1}\right)\end{array}$ \\
\hline Control & $74.80^{\mathrm{NS}}$ & $73.70 \mathrm{a}$ & $5.19 \mathrm{a}$ & $10.30 \mathrm{a}$ & $1.57 \mathrm{a}$ \\
\hline Ethephon 2,160-20DAP & 76.74 & $95.11 \mathrm{~b}$ & $7.02 \mathrm{~b}$ & $15.30 \mathrm{ab}$ & $2.93 \mathrm{~b}$ \\
\hline Ethephon $1,440-20 \mathrm{DAP}$ & 81.59 & $91.73 \mathrm{~b}$ & $6.97 \mathrm{~b}$ & $17.80 \mathrm{ab}$ & $3.38 \mathrm{~b}$ \\
\hline Ethephon 2,160-15DAP & 78.09 & $92.06 \mathrm{~b}$ & $6.84 \mathrm{~b}$ & $18.60 \mathrm{~b}$ & $3.32 \mathrm{~b}$ \\
\hline Ethephon $1,440-15 \mathrm{DAP}$ & 79.63 & $93.33 \mathrm{~b}$ & $6.78 \mathrm{~b}$ & $18.70 \mathrm{~b}$ & $3.39 \mathrm{~b}$ \\
\hline \multicolumn{6}{|c|}{ Agricultural year 2012/2013 } \\
\hline Control & $97.10^{\mathrm{NS}}$ & $38.61 \mathrm{a}$ & $4.02 \mathrm{a}$ & $4.80 \mathrm{a}$ & $1.13 \mathrm{a}$ \\
\hline Ethephon 2,160-20DAP & 89.02 & $89.65 \mathrm{~b}$ & $6.96 \mathrm{~b}$ & $15.60 \mathrm{~b}$ & $4.49 \mathrm{~b}$ \\
\hline Ethephon 1,440-20DAP & 95.62 & $88.55 \mathrm{~b}$ & $6.60 \mathrm{~b}$ & $15.90 \mathrm{~b}$ & $3.53 \mathrm{~b}$ \\
\hline Ethephon 2,160-15DAP & 97.07 & $83.45 \mathrm{~b}$ & $6.58 \mathrm{~b}$ & $15.20 \mathrm{~b}$ & $3.77 \mathrm{~b}$ \\
\hline Ethephon 1,440-15DAP & 92.40 & $82.83 \mathrm{~b}$ & $7.01 \mathrm{~b}$ & $15.90 \mathrm{~b}$ & $4.68 \mathrm{~b}$ \\
\hline
\end{tabular}

Means followed by the same letter in the columns do not differ by Tukey test at $5 \%$ probability. DAP = Days before the production pruning. Control $=$ without application of ethephon. $\mathrm{NS}=$ not significative.

TABLE 2 - Length, width and clusters weight, berries diameter, soluble solids (SS) and titratable acidity (TA) in Niagara Rosada vines depending on ethephon application before summer pruning in the county of Atibaia-SP.

\begin{tabular}{|c|c|c|c|c|c|c|}
\hline \multicolumn{7}{|c|}{ Agricultural year 2011/2012 } \\
\hline Treatment & $\begin{array}{c}\text { Length } \\
\text { (mm) }\end{array}$ & $\begin{array}{r}\text { Width } \\
\text { (mm) }\end{array}$ & $\begin{array}{c}\text { Clusters } \\
\text { Weight (g) }\end{array}$ & $\begin{array}{c}\text { Berries } \\
\text { Diameter } \\
(\mathbf{m m})\end{array}$ & $\begin{array}{c}\text { SS } \\
{ }^{\circ} \text { Brix }\end{array}$ & $\begin{array}{l}\text { TA } \\
\%\end{array}$ \\
\hline Control & $102.24 \mathrm{a}$ & $60.37 \mathrm{a}$ & $152.84 \mathrm{a}$ & $18.74 \mathrm{c}$ & $11.90 \mathrm{~b}$ & $1.17 \mathrm{~b}$ \\
\hline Ethephon 2,160-20DAP & $129.82 \mathrm{c}$ & $66.29 \mathrm{~b}$ & $209.66 \mathrm{bc}$ & $18.19 \mathrm{ab}$ & $11.67 \mathrm{ab}$ & $1.18 \mathrm{~b}$ \\
\hline Ethephon 1,440-20DAP & $129.01 \mathrm{c}$ & $68.71 \mathrm{~b}$ & $234.17 \mathrm{c}$ & $18.20 \mathrm{ab}$ & $11.57 \mathrm{ab}$ & $0.92 \mathrm{a}$ \\
\hline Ethephon 2,160-15DAP & $115.84 b$ & $66.97 \mathrm{~b}$ & $195.32 \mathrm{~b}$ & $18.36 \mathrm{~b}$ & $11.59 \mathrm{ab}$ & $1.10 \mathrm{ab}$ \\
\hline Ethephon 1,440-15DAP & $129.30 \mathrm{c}$ & $69.03 \mathrm{~b}$ & $231.37 \mathrm{c}$ & $18.10 \mathrm{a}$ & $11.17 \mathrm{a}$ & $1.08 \mathrm{ab}$ \\
\hline \multicolumn{7}{|c|}{ Agricultural year 2012/2013 } \\
\hline Control & $112.15 \mathrm{a}$ & $59.07 \mathrm{a}$ & $150.41 \mathrm{a}$ & $17.03 \mathrm{a}$ & $12.21 \mathrm{~b}$ & $0.90 \mathrm{~b}$ \\
\hline Ethephon 2,160-20DAP & $134.66 \mathrm{c}$ & $68.89 \mathrm{c}$ & $237.56 \mathrm{c}$ & $17.62 \mathrm{~b}$ & $11.09 \mathrm{a}$ & $0.78 \mathrm{ab}$ \\
\hline Ethephon 1,440-20DAP & $132.97 \mathrm{bc}$ & $65.31 \mathrm{bc}$ & $220.24 \mathrm{bc}$ & $17.66 \mathrm{~b}$ & $11.07 \mathrm{a}$ & $0.77 \mathrm{ab}$ \\
\hline Ethephon 2,160-15DAP & $127.25 \mathrm{~b}$ & $63.22 \mathrm{~b}$ & $215.15 \mathrm{bc}$ & $17.61 \mathrm{~b}$ & $11.24 \mathrm{a}$ & $0.81 \mathrm{ab}$ \\
\hline Ethephon $1,440-15 \mathrm{DAP}$ & $127.37 \mathrm{bc}$ & $64.38 \mathrm{~b}$ & $208.48 \mathrm{~b}$ & $17.49 \mathrm{~b}$ & $11.15 \mathrm{a}$ & $0.74 \mathrm{a}$ \\
\hline
\end{tabular}

Means followed by the same letter in the columns do not differ by Tukey test at $5 \%$ probability. DAP = Days before the production pruning. Control $=$ no the application of ethephon. 


\section{CONCLUSIONS}

The application of ethephon in vines mature leaves, before the summer production pruning stimulates leaf drop induces sprouting, alters the development of the plant and its production, but this is not due to the increased concentration of carbohydrates reserves in the branches but to the greatest stimulus to sprouting.

The greatest stimulus to sprouting makes the plants to express the greatest production capacity.

The ethephon application at a concentration of $1,440 \mathrm{mg} \mathrm{L}^{-1}$, is sufficient to alter plant development and can be applied 15 days before summer pruning production.

\section{ACKNOWLEDGMENT}

We thank FAPESP for financial support.

\section{REFERÊNCES}

BENNETT, J.; JAVIS, P.; CREASY, G.L.; THROUGHT, M.C.T. Influence of defoliation on overwintering carbohydrate reserves, return bloom, and yield of mature Chardonnay grapevines. American Journal of Enology and Viticulture, Davis, v.56, n.4 p.386-393, 2005.

BOTELHO, R.V.; PIRES, E.J.P.; TERRA, M.M. Brotação e produtividade de videiras da cultivar Centenial Seedless (Vitis vinifera L.) tratadas com cianamida hidrogenada na região noroeste do Estado de São Paulo. Revista Brasileira de Fruticultura, Jaboticabal, v.24, n.3, p.611-614, 2002.

CANDOLFI-VASCONCELOS M.C.; KOBLET, W. Yield, fruit quality, bud fertility and starch reserves of the wood as a function of leaf removal in Vitis vinifera: evidence of compensation and stress recovering. Vitis, Quedlinburg, v.29, p.199-221, 1990.

CANDOLFI-VASCONCELOS, M.C.; GREVEN, M.; WINEFIELD, C.S.; TROUGHT, M.C.T.; AW, $\mathrm{V}$. The flowering process of Vitis vinifera: a review. American Journal of Enology and Viticulture, Davis, v.60, p.411-434, 2009.
CARVALHO, C.R.L.; MONTOVANI, D.M.B.; CARVALHO, P.R.N.; MORAES, R.M.M. Análises químicas de alimentos. Campinas: ITAL, 1990. $121 \mathrm{p}$.

CEPAGRI. Centro de Pesquisas Meteorológicas e Climáticas Aplicadas à Agricultura. Cidade Universitária “Zeferino Vaz" Campinas/SP. 2014. Disponível em: $<\underline{\text { http://www.cpa.unicamp.br/outras- }}$ informacoes/clima muni 456.html $>$ Acesso em: 20 nov. 2014

DOKOOZLIAN, N. K.; WILLIAMS, L. E.; NEJA, R. A. Chilling exposure and hydrogen cyanamide interact in breaking dormancy of grape buds HortScience, Alexandria, v.30, n.6, p. 1244-1247, 1995.

DUBOIS, M.; GILLES, K.A.; HAMILTON, J.K.; REBERS, P.A.; SMITH, F. Colorimetric method for determination of sugars and related substances. Analytical Chemistry, Washington, v.28, p.350$356,1956$.

EICHHORN, K.W.; LORENZ, D.H. Phaenologische entwicklungsstadien der rebe. European and Mediterranean Plant Protection Organization, Paris, v.14, n.2, p.295-298, 1984.

FRACARO, A.A.; PEREIRA, F.M.; NACHTIGAL, J.C.; BARBOSA, J.C. Efeitos do ethephon sobre a produção da uva 'Niagara Rosada' (Vitis labrusca L.), produzida na entressafra na região de Jales-SP. Revista Brasileira de Fruticultura, Jaboticabal, v.26, n.1, p. 82-85, 2004.

HAWERROTH, F.J.; MARTINS, M.V.V.; AZEVEDO, A.E.C. Uso da desfolha para indução da brotação de atemoleira 'Gefner'. Revista Brasileira de Fruticultura, Jaboticabal, v.36, n. 4, p.1041$1045,2014$.

HOLZAPFEL, B.P.; SMITH J.P.; MANDEL, R.M.; KELLER, M. Manipulating the postharvest period and its impact on vine productivity of semillon grapevines. American Journal of Enology and Viticulture, Davis, v.57, n.2, p.148-157, 2006.

IEA - Instituto de Economia Agrícola. Banco de dados IEA. Brasília: Ministério da Integração Nacional, 2014. Disponível em: $<$ http://www. integracao.gov.br>. Acesso em: 25 nov. 2014. 
KÖEPPEN, W. P.; GEIGER, R. Das geographische system der klimate. In: KÖPPEN, W.; GEIGER, R. Handbuch der klimatologie. Berlin: Borntrager, 1936. v.1, part c.

LEÃO, P.C.S.; LIMA, M.A.C.; COSTA, J.P.D.; TRINDADE, D.C.G. Abscisic acid and ethephon for improving red color and quality of crimson seedless grapes grown in a tropical region. American Journal of Enology and Viticulture, Davis, v. 66, n.1, p. 37-45, 2015.

MIELE, A. Efeito da cianamida hidrogenada na quebra de dormência das gemas, produtividade do vinhedo e composição química do mosto da uva Cabernet Sauvignon. Pesquisa Agropecuária Brasileira, Brasília, v.26, n.3, p.315-354, 1991.

NENDEL, C. Grapevine bud break prediction for cool winter climates. International Journal of Biometeorology, Heidelberg, v.54, p.231-241, 2010.

PELLEGRINO, A.; CLINGELEFFER, P.; COOLEY, N.; WALKER, R. Management practices impact vine carbohydrate status to a greater extent than vine productivity. Frontier in Plant Science, Lausanne, v.5, p.1-13, 2014.

PIRES, E.J.P.; POMMER, C.V.; TERRA, M.M.; PASSOS, I.R.S. Effects de la cyanamide de calcium et de la cyanamide hydrogéne sur la levée de dormance dês bourgeons, lê débourrement et lê rendement du cépage Niágara Rose dans la région de Jundiaí, État de São Paulo, Brésil. Bulletin de L' OIV, Paris, v.72, p.457-483, 1999.

PONI, S.; CASALINI, L.; BERNIZZONI, C.S.; CIVARDI, S.; INTRIERI C. Effects of early defoliation on shoot photosynthesis yield components, and grape composition. American Journal of Enology and Viticulture, Davis, v.57, n. 4, p.397-407, 2006.

ROSA, A.M.; PESCADOR, R.; SILVA, A.L.; BRIGHENTI, A.F.; BRUNETTO, G. Fertilidade e reservas de carbono e nitrogênio em gemas de ramos das viníferas'Carbernet Sauvignon' e 'Nebbiolo'. Revista Brasileira de Fruticultura, Jaboticabal, v.36, n. 3, p.576-585, 2014.
SABBATINI, P.; HOWELL, G.S. Effects of Early Defoliation on Yield, Fruit Composition, and Harvest Season Cluster Rot Complex of Grapevines. HortScience, Alexandria, v.45, n.12, p.1804-1808, 2010.

SCARPARE, F.V.; SCARPARE FILHO, J.A.; RODRIGUES, A.; REICHARDT, K.; ANGELOCCI, L. R. Growing degree-days for the 'Niagara Rosada' grapevine pruned in different seasons. International Journal of Biometeorology, Heidelberg, v.56, p.823-30, 2011.

SHIKHAMANY, S.D. Physiology and cultural practices to produce seedless grapes in tropical environments. In: CONGRESSO BRASILEIRO DE VITICULTURA E ENOLOGIA, 9., 1999, Bento Gonçalves. Anais... Bento Gonçalves: EmbrapaCNPUV, 1999. p.43-48.

SHULMAN, Y.; NIR, G.; LAVEE, S. Oxidative processes in bud dormancy and the use of hydrogen cyanamide in breaking dormancy. Acta Horticulturae, The Hague, v.179, p.141-148, 1986.

SMITH, J.P.; HOLZAPFEL, B.P. Cumulative responses of semillon grapevines to late season perturbation of carbohydrate reserve status. American Journal of Enology and Viticulture, Davis, v. 60, n.4, 2009.

SRINIVASAN, C.; MULLINS, M.G. Physiology of flowering in the grapevine - A review. American Journal of Enology and Viticulture, Davis, v.32, p.47-63, 1981.

WALKER, D. R.; SEELEY, S. D. The rest mechanism in deciduous tree fruits as influenced by plant growth substances. Acta Horticulturae, The Hague, v.34, p.225-234, 1973.

WERLE, T.; GUIMARÃES, V. F.; DALASTRA, I. M.; ECHER, M. M.; PIO, R. Influência da cianamida hidrogenada na brotação e produção da videira 'Niagara Rosada' na região oeste do Paraná. Revista Brasileira de Fruticultura, Jaboticabal, v.30, n.1, p.20-24, 2008.

ZUFFEREY, V.; MURISIER F.; VIVIN, P.; BELCHER, S.; LORENZINI, F.; SPRING, J. L.; VIRET, O. Carbohydrate reserves in grapevine (Vitis vinifera L. 'Chasselas'): the influence of the leaf to fruit ratio. Vitis, Quedlinburg, v.51, p.103-110, 2012. 